\title{
Laminarin Elicits Defense Responses in Grapevine and Induces Protection Against Botrytis cinerea and Plasmopara viticola
}

\author{
Aziz Aziz," Benoît Poinssot, ${ }^{2}$ Xavier Daire, ${ }^{2}$ Marielle Adrian, ${ }^{2,3}$, Annie Bézier, ${ }^{1}$ B. Lambert, ${ }^{1}$ Jean-Marie \\ Joubert, ${ }^{4}$ and Alain Pugin ${ }^{2}$ \\ 'Unité de Recherche Vignes et Vins de Champagne, URVVC - UPRES EA 2069, UFR Sciences, Moulin de la Housse, \\ Université de Reims Champagne-Ardenne, BP 1039, F-51687 Reims cedex 2 France; ${ }^{2}$ Unité Mixte de Recherche, Plante- \\ Microbe-Environnement, INRA 1088/CNRS 2625/ Université de Bourgogne, 17 rue Sully, BP 86510, 21065 Dijon cedex, \\ France; ${ }^{3}$ Institut Jules Guyot, UMR 1088 INRA/Université de Bourgogne, 17 rue Sully, BP 86510, 21065 Dijon cedex, \\ France; ${ }^{4}$ Société Goëmar, Avenue du Général Patton, BP 55, 35413 Saint Malo cedex, France
}

Submitted 21 April 2003. Accepted 30 June 2003.

Grapevine (Vitis vinifera $\mathrm{L}_{\text {.) }}$ is susceptible to many pathogens, such as Botrytis cinerea, Plasmopara viticola, Uncinula necator, and Eutypa lata. Phytochemicals are used intensively in vineyards to limit pathogen infections, but the appearance of pesticide-resistant pathogen strains and a desire to protect the environment require that alternative strategies be found. In the present study, the $\beta$-1,3-glucan laminarin derived from the brown algae Laminaria digitata was shown both to be an efficient elicitor of defense responses in grapevine cells and plants and to effectively reduce $B$. cinerea and $P$. viticola development on infected grapevine plants. Defense reactions elicited by laminarin in grapevine cells include calcium influx, alkalinization of the extracellular medium, an oxidative burst, activation of two mitogen-activated protein kinases, expression of 10 defense-related genes with different kinetics and intensities, increases in chitinase and $\beta-1,3$-glucanase activities, and the production of two phytoalexins (resveratrol and $\varepsilon$-viniferin). Several of these effects were checked and confirmed in whole plants. Laminarin did not induce cell death. When applied to grapevine plants, laminarin reduced infection by $B$. cinerea and $P$. viticola by approximately 55 and $75 \%$, respectively. Our data describing a large set of defense reactions in grapevine indicate that the activation of defense responses using elicitors could be a valuable strategy to protect plants against pathogens.

The spread of a plant disease is governed by the abilities of the plant and its potential pathogen to react quickly to new signals generated during the molecular dialogue between both partners. In plants, a complex array of defense responses is induced after detection of a microorganism via the recognition of elicitor molecules released during the plant-pathogen interaction (Ebel and Cosio 1994). Following elicitor perception, the activation of signal transduction pathways generally leads to the production of active oxygen species (AOS), phytoalexin biosynthesis, reinforcement of plant cell walls, and the accumulation of patho-

Corresponding author: A. Pugin, E-mail: pugin@dijon.inra.fr; Fax: 33-380-69-32-26.

Current address of B. Poinssot: Department of Plant Biology, University of Fribourg, 1700, Switzerland.

A. Aziz and B. Poinssot contributed equally to this article. genesis-related (PR) proteins, some of which possess antimicrobial properties (Fritig et al. 1998; Hammerschmidt 1999; Somssich and Hahlbrock 1998; Van Loon and Van Strien 1999). All these defense reactions, which sometimes are associated with a localized cell death known as the hypersensitive reaction (HR), are considered to be important responses for delimiting the pathogen's growth. Moreover, plants have the ability to develop systemic acquired resistance (SAR), which reduces subsequent infection of healthy tissues by a broad range of pathogens. However, if these defense reactions occur too late, the infection process will spread successfully.

Various types of elicitors have been characterized, including carbohydrate polymers, lipids, (glyco)peptides, and (glyco)proteins. These products are secreted by microorganisms or derived from the cell walls of fungi, bacteria, or host plants (Côté and Hahn 1994; Ebel and Cosio 1994) or from seaweed (Bouarab et al. 1999; Klarzynski et al. 2000; Potin et al. 1999). Among them, ramified $\beta-(1,3)-(1,6)-$ glucans, xyloglucans, oligogalacturonides, and chitin or chitosan oligomers exhibit elicitor activity across different plant species and evoke pathogen defense responses (Côté and Hahn 1994; Côté et al. 1998; Darvill et al. 1992; John et al. 1997; Sharp et al. 1984).

The chemically well-characterized heptaglucoside from the pathogenic oomycete Phytophthora sojae (Cheong and Hahn 1991; Sharp et al. 1984) has been shown to highly induce phytoalexin biosynthesis even when applied at low nanomolar concentrations (Brady et al. 1993; Côté and Hahn 1994). Similarly, linear $\beta$-1,3-glucan oligomers are recognized as elicitors by a variety of plants, such as alfalfa (Cardinale et al. 2000), bean (Mithöfer et al. 1999), and rice (Inui et al. 1997). The linear $\beta$ 1,3-glucan laminarin derived from the brown algae Laminaria digitata elicits a variety of defense reactions in tobacco plants, such as the stimulation of phenylalanine ammonia lyase, caffeic acid O-methyl transferase, and lipoxygenase activities, as well as the accumulation of salicylic acid and PR proteins (Klarzynski et al. 2000). Furthermore, certain glucans have been reported to enhance resistance against viruses (Rouhier et al. 1995) and bacteria (Klarzynski et al. 2000).

Grapevine (Vitis vinifera L.) is susceptible to many diseases, such as gray mould (Botrytis cinerea), downy mildew (Plasmopara viticola), powdery mildew (Uncinula necator), and dieback (Eutypa lata). Phytochemicals commonly are used in vineyards to prevent and limit pathogen infections. However, because of the development of pesticide-resistant pathogen strains (Leroux 
et al. 1999), and in an effort to preserve wine quality and yet reduce the impact of pesticides on the environment, considerable interest has been focused on the replacement of chemicals by efficient, alternative strategies. Grapevine resistance could be increased by genetic improvement, but hybrids and transformed grapevine (Coutos-Thévenot et al. 2001) are forbidden in French vineyards. Thus, the alternative strategies most commonly involve biological control of pathogens, or else the activation of plant defense mechanisms using elicitors.

In $V$. vinifera, only a few defense markers have been investigated in leaves and berries. Most of studies have concentrated on gene expression and activities of chitinases and glucanases (Bézier et al. 2002a; Busam et al. 1997; Derckel et al. 1996, 1998; Robert et al. 2002; Robinson et al. 1997; Salzman et al. 1998) and the production of stilbenic phytoalexins (Adrian et al. 1997; Bais et al. 2000; Jeandet et al. 1991; Langcake and Pryce 1977a and b; Pryce and Langcake 1977). Recently, we reported a large set of defense responses triggered by the endopolygalacturonase 1 of $B$. cinerea in grapevine (Poinssot et al. 2003).
In the present study, we report that laminarin is a potent elicitor of defense reactions in grapevine cells. The early responses triggered by laminarin include calcium influx, an oxidative burst, extracellular alkalinization of the culture medium, and mitogen-activated protein kinase (MAPK) activation. Laminarin induces the expression of defense genes associated with the octadecanoid, phenylpropanoid, and stilbenoid pathways, and those corresponding to PR proteins. Moreover, laminarin induces a significant protection of grapevine leaves against two pathogens, $B$. cinerea and $P$. viticola.

\section{RESULTS}

\section{Early signaling events induced}

by laminarin in grapevine cell suspensions.

The production of $\mathrm{H}_{2} \mathrm{O}_{2}$ increased with increasing concentrations of laminarin and became saturated at between 0.5 and 1 g/liter (Fig. 1A). The oxidative burst was detected approximately 10 min after laminarin application and the $\mathrm{H}_{2} \mathrm{O}_{2}$ pro-

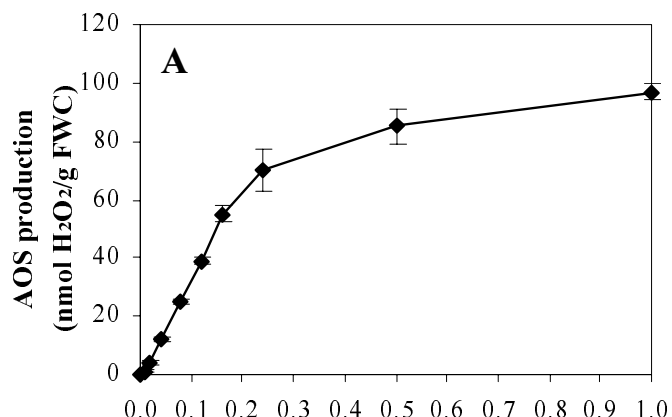

Laminarin $(g / L)$

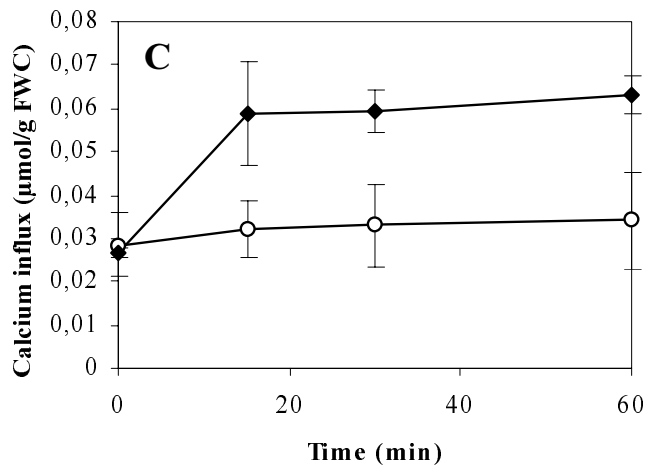

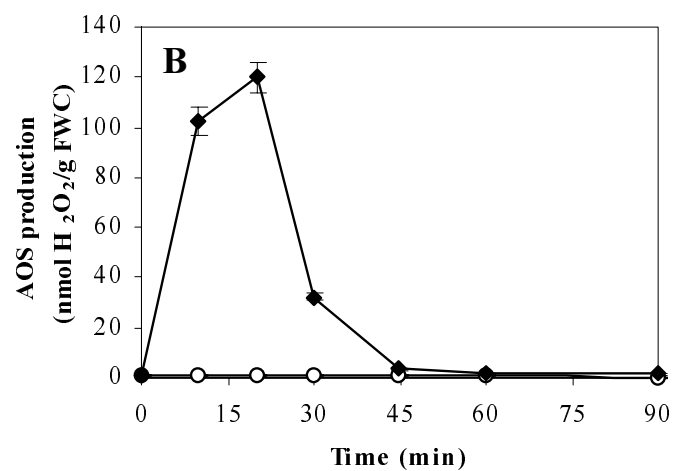

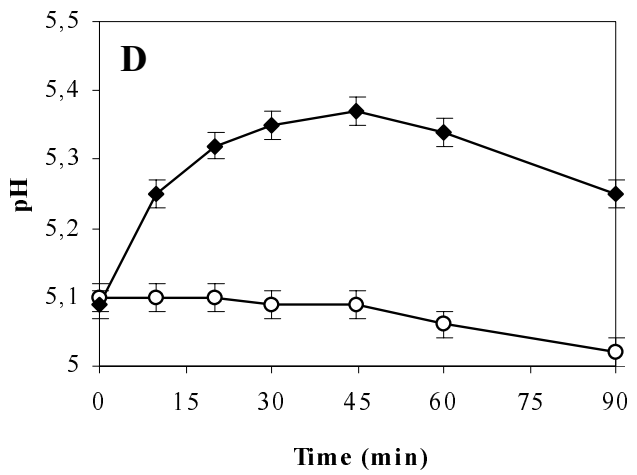

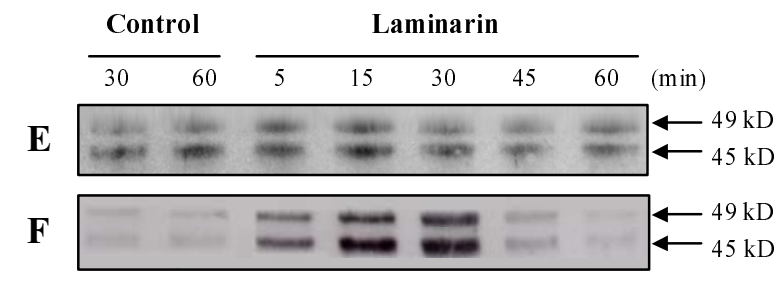

Fig. 1. Early signaling events activated in grapevine cells after elicitation with laminarin. A, Dose-response curve of active oxygen species (AOS) production in grapevine cell suspensions, 10 min after treatment with increasing concentrations of laminarin $(\bullet)$. $\mathrm{H}_{2} \mathrm{O}_{2}$ production was measured using chemiluminescence of luminol. B, Time-course AOS production in grapevine cell suspensions treated with laminarin at $1 \mathrm{~g} /$ /iter $(\bullet)$ or in untreated cell suspensions $(\bigcirc)$. C, Kinetic of calcium influx in grapevine cells treated by laminarin at $1 \mathrm{~g} /$ liter $(\bullet)$ or in control cells $(\mathrm{O})$. Calcium influx was measured by ${ }^{45} \mathrm{Ca}^{2+}$ incorporation, added 5 min before treatment $(0,033 \mathrm{MBq} / \mathrm{g}$ of fresh weight of cells). D, Extracellular $\mathrm{pH}$ shift of grapevine cell suspensions treated by laminarin at $1 \mathrm{~g} / \mathrm{liter}(\bullet)$ or untreated (O). $\mathbf{E}$ and $\mathbf{F}$, Kinetics of activation of two mitogen-activated protein kinases in control grapevine cells or treated by laminarin at $1 \mathrm{~g} /$ liter, $\mathbf{E}$, analyzed by Western blot using an antibody raised against human nonactivated ERK1/2 or F, raised against a phosphorylated peptide contained in the human ERK1/2. Protein extracts $(15 \mu \mathrm{g})$ were separated on $12 \%$ sodium dodecyl sulfate-polyacrylamide gel electrophoresis before transfer onto nitrocellulose membrane and Western blot analysis. Results are from one representative experiment out of three. Values represent the average data \pm SD of triplicate assays. 
duction was maximal after a further $10 \mathrm{~min}$ (Fig. 1B). Thereafter, $\mathrm{H}_{2} \mathrm{O}_{2}$ concentration in the medium declined, reaching its initial level $45 \mathrm{~min}$ after the beginning of the treatment.

Calcium influx has been shown to mediate elicitor-induced defense responses (Blume et al. 2000; Jabs et al. 1997; Lecourieux et al. 2002; Tavernier et al. 1995; Yang et al. 1997). Laminarin induced a rapid uptake of ${ }^{45} \mathrm{Ca}^{2+}$ in cultured grapevine cells (Fig. 1C) in a dose-dependent manner, with $1 \mathrm{~g} /$ liter being the most efficient concentration (data not shown). The increase in $\mathrm{Ca}^{2+}$ influx started within a few minutes, then reached a maximum value after 15 min corresponding to $60 \mathrm{nmol}$ per gram of fresh weight of cells (FWC). In control cells, the basal level of $\mathrm{Ca}^{2+}$ remained unchanged.

Alkalinization of the incubation medium has been reported many times for elicitor-treated cell suspensions (Felix et al. 1993, 1998; Küpper et al. 2001; Mathieu et al. 1996). Treatment of grapevine cells with laminarin at $1 \mathrm{~g} /$ liter caused an increase in the $\mathrm{pH}$ of the medium from 5.12 to 5.35 within 30 min (Fig. 1D). Thereafter, the $\mathrm{pH}$ decreased slowly to 5.26 at 90 min after the beginning of the treatment.

A rapid activation of MAPKs has been described for different plant systems in response to elicitors (Gomez-Gomez and Boller 2002; Lebrun-Garcia et al. 1998; Romeis et al. 1999; Zhang et al. 1998). In our control and laminarin (1 g/liter)treated grapevine cells, total MAPKs were quantified using an antibody raised against human nonactivated ERK1/2. Western blots performed with this antibody revealed two MAPKs with relative molecular masses of 49 and $45 \mathrm{kDa}$, respectively, and with comparable intensities in both control and laminarintreated cells (Fig. 1E). Thereafter, the time course of activation of MAPKs in grapevine cells was analyzed using an antibody raised against a phosphorylated peptide contained in the human active ERK1/2. Immunodetection with this last antibody revealed a rapid and transient activation of both MAPKs (Fig. $1 F)$ only in laminarin-treated cells. Their activation was detected within $5 \mathrm{~min}$ of treatment, peaked after 15 to $30 \mathrm{~min}$, and then fell to undetectable levels after $60 \mathrm{~min}$.

\section{Defense-related gene expression}

in laminarin-treated grapevine cells and plants.

In grapevine, most elicitor- or pathogen-induced cDNA that has been cloned corresponds to genes encoding PR proteins (Busam et al. 1997; Davies and Robinson 2000; Jacobs et al. 1999; Robert et al. 2001, 2002) or enzymes involved in the synthesis of stilbene phytoalexins (Melchior and Kindl 1990, 1991; Sparvoli et al. 1994; Wiese et al. 1994). To our knowledge, many other putative defense genes, such as $P R-1$ and $P D F 1.2$, have not yet been identified in this species. For our study, grapevine cells were challenged with laminarin at the saturating concentration of $1 \mathrm{~g} / \mathrm{liter}$, and the expression pattern of 11 selected defense-related genes was analyzed using real time quantitative polymerase chain reaction (rtq-PCR) and specific primers (Table 1) with an actin gene as internal standard (Bézier et al. 2002a). The rtq-PCR analysis gave reproducible results that were confirmed using RNA gel blot analysis (data not shown). In control cells, transcript accumulation of the different genes was always very low during the 25 -h incubation period (data not shown).

In grapevine cells treated with laminarin, 9-lipoxygenase $(L O X)$ and glutathione-S-transferase (GST) genes were rapidly and transiently up-regulated (Fig. 2A). The steady state levels of mRNA for LOX and GST increased $1 \mathrm{~h}$ after laminarin was supplied, and were maximal (35- and 65-fold higher, respectively, than in control cells at time zero) after 2 and $5 \mathrm{~h}$ of treatment, respectively. mRNA levels subsequently decreased slowly.

Phenylalanine ammonia lyase (PAL) is a key enzyme of the phenylpropanoid pathway which leads to various defenserelated compounds. Downstream of PAL, stilbene synthase 1 (STS1) is responsible for the synthesis of resveratrol, the main phytoalexin produced by grapevine in response to biotic or abiotic stresses (Adrian et al. 1997; Coutos-Thévenot et al. 2001; Langcake and Pryce 1977a and b). In laminarin treated-cells, $P A L$ and STS1 mRNA were detected after $1 \mathrm{~h}$ of treatment, and reached a 20-fold higher level than in control cells after $5 \mathrm{~h}$. Thereafter, transcripts of both slowly declined (Fig. 2A).

We also focused on a PGIP gene for which the product, a polygalacturonase-inhibiting protein (PGIP), interacts with extracellular endo- $\alpha-1,4$-polygalacturonases (PGs) secreted by phytopathogenic fungi to inhibit their activity (Caprari et al. 1996). In laminarin-treated cells, $P G I P$ transcript accumulation was detectable after $10 \mathrm{~h}$ of treatment and reached a 40 -fold accumulation after $20 \mathrm{~h}$ (Fig. 2A).

The mRNA accumulation of three genes encoding chitinases has been shown to be differentially regulated in grapevine when challenged with $U$. necator, $P$. viticola, B. cinerea, or Pseudomonas syringae pv. pisi (Busam et al. 1997; Jacobs et al. 1999; Robert et al. 2002). Basic class I (CHIT1b), acidic class III (CHIT3), and acidic class IV (CHIT4c) chitinase cDNAs were cloned from grapevine cells (Busam et al. 1997) or leaves (A. Bézier, personal communication) from various cultivars. In laminarin-treated grapevine cells, the expression of the three genes increased from $1 \mathrm{~h}$ of treatment and reached a maximum between 5 and $10 \mathrm{~h}$, with an approximately 140fold, 30-fold, and 700-fold increase for CHIT1b, CHIT3, and $C H I T 4 c$, respectively. Thereafter, transcript accumulation remained constant (CHIT3) or else decreased slowly (CHITIb

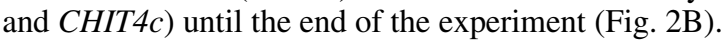

The class I $\beta$-1,3-glucanases are antifungal vacuolar proteins implicated in plant defense which exhibit developmental, hormonal, and pathogenesis-related regulation. The antifungal ac-

Table 1. Sequences of defense gene primers used for real time quantitative polymerase chain reaction ${ }^{\mathrm{a}}$

\begin{tabular}{lll}
\hline Names & \multicolumn{1}{c}{ Forward primers } & \multicolumn{1}{c}{ Reverse primers } \\
\hline CHIT3 & 5'-AGATGGCATAGACTTCGACA-3' & 5'-GTACTTTGACCACAGCATCA-3' \\
CHIT4c & 5'-GCAACCGATGTTGACATATCA-3' & 5'-CTCACTTGCTAGGGCGACG-3' \\
CHIT1b & 5'-ATGCTGCAGCAAGTTTGGTT-3' & 5'-CATCCTCCTGTGATGACATT-3' \\
GLU & 5'-ATGCTGGGTGTCCCAAACTCG-3' & 5'-CAGCCACTCTCCGACAGCAC-3' \\
LOX & 5'-GCATGGGGTAAGAGGTGCATG-3' & 5'-GCCTTGTTGTGATGTAATTGG-3' \\
$P A L$ & 5'-CTGGGTGGCTTCTGCTCTC-3' & 5'-GATAAGCCGCAGATTCATGC-3' \\
$P I N$ & 5'-TGACCACTTGACTCACAAAT-3' & 5'-ACTAGGTATGTGGTAGACAT-3' \\
STS 1 & 5'-AGTTCAGGGAGAGGTTGCTG-3' & 5'-GCACTAGGGTCCGTGTTTGGGTCGACG-3' \\
$H S R$ & 5'-TACGCCAAGAGATTATCACT-3' & 5'-CTAAAGAGTCCAAAGCATCT-3' \\
$P G I P$ & 5'-GGACTACCGACATGCACCTG-3' & 5'-GGTCATCACAAGCCTCTTGC-3' \\
\hline
\end{tabular}

${ }^{a}$ CHITIb and CHIT3 (Busam et al. 1997), PAL and STS1 (Sparvoli et al. 1994), HSR (Bézier et al. 2002b), and PGIP (Bézier et al. 2002a). Other sequences from A. Bézier and F. Bailleul, personal communication. Accession numbers: CHIT4c, no. AY137377; GLU1, no. AF239617; GST, no. AY156048; LOX, no. AY159556; and PIN, no. AY156047. 

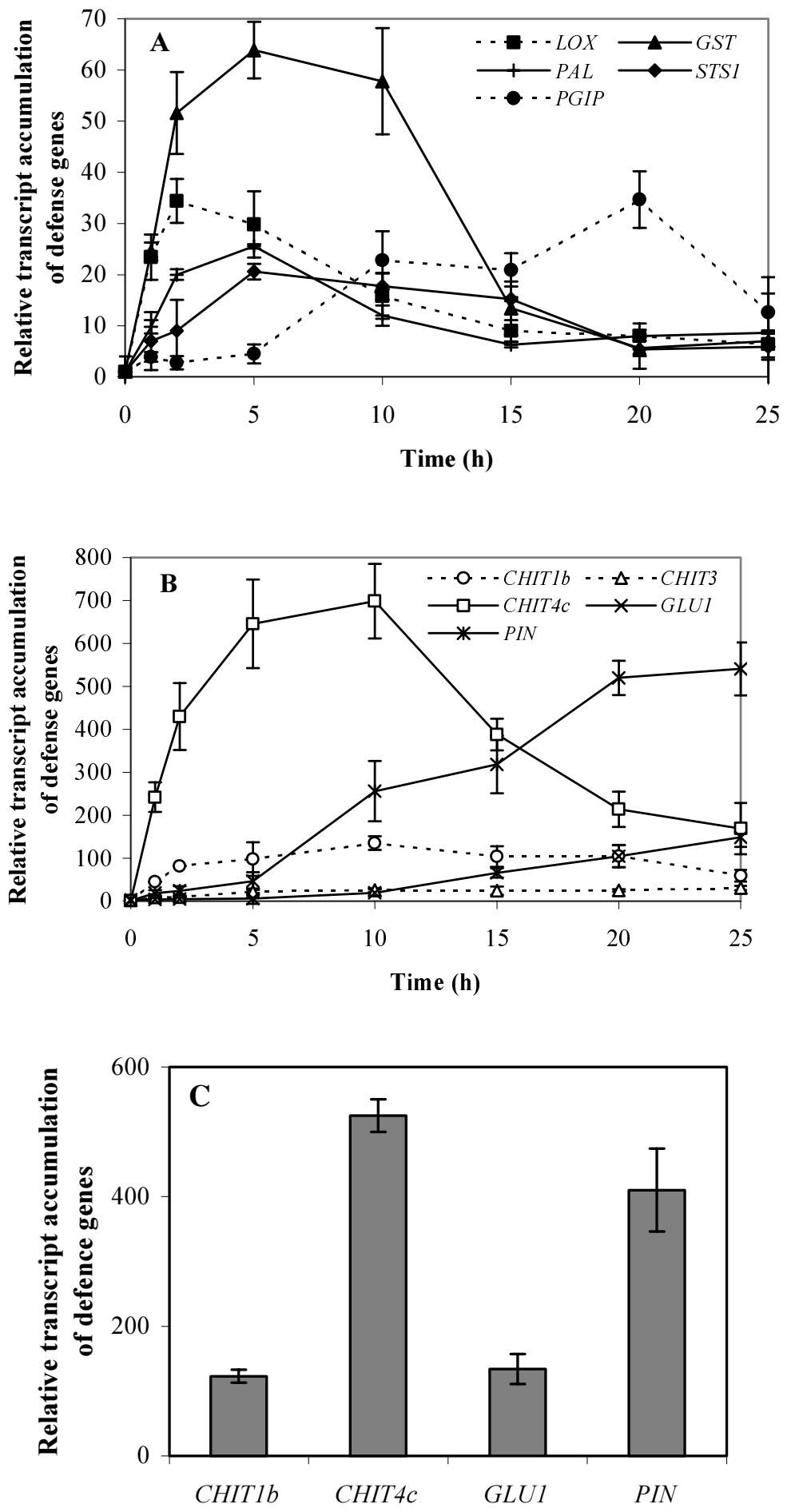

Fig. 2. Transcript accumulation of defense genes in grapevine cells after elicitation by laminarin. A, Expression profiles of defense-related genes encoding a lipoxygenase (LOX, accession no. AY159556), a glutathion-S-transferase (GST, accession no. AY156048), a polygalacturonase-inhibiting protein (PGIP; Bézier et al. 2002a), a phenylalanine ammonia lyase (PAL; Sparvoli et al. 1994), and a stilbene synthase (STS1; Sparvoli et al. 1994) in grapevine cells treated with laminarin at $1 \mathrm{~g} /$ liter. B, Expression profiles of pathogenesis-related $(P R)$ genes encoding a basic $\beta-1,3$-glucanase (GLU1, accession no. AF239617), a serineproteinase inhibitor (PIN, accession no. AY156047), a basic chitinase (CHITlb; Busam et al. 1997), and two acidic chitinases of class III (CHIT3; Busam et al. 1997) and class IV (CHIT4c, accession no. AY137377) in grapevine cells treated with laminarin at $1 \mathrm{~g} /$ liter. Analyses were performed by real time quantitative polymerase chain reaction (rtq-PCR). Levels of transcripts were calculated using the standard curve method from triplicate data, with grapevine actin gene as internal control and nontreated cells (zero time) as reference sample. Results represent the mean fold increase of mRNA level over nontreated cells, referred as the $1 \times$ expression level. Absolute copy number of mRNA for each target gene in the reference sample was $10($ GLU1), 1,633 (PIN), $494($ CHIT1b), 1,194

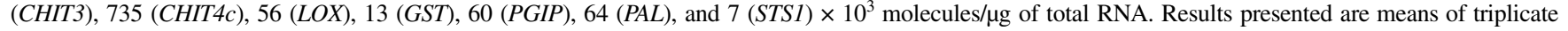
data \pm SD of one representative experiment out of three. C, Expression of PR genes in grapevine detached leaves after $24 \mathrm{~h}$ of treatment with laminarin at 1 $\mathrm{g} /$ liter. Detached leaves were incubated for $24 \mathrm{~h}$ on aqueous solutions containing laminarin at $1 \mathrm{~g} /$ /iter before inoculation with a conidial suspension $\left(5 \times 10^{5}\right.$ conidia/ml) of Botrytis cinerea, and rtq-PCR was performed as described above. In control leaves, the transcript level of defense genes was very low. Values represent the mean $\pm \mathrm{SD}$ of triplicates of one representative experiment out of two. 
tivity of plant $\beta$-1,3-glucanases is thought to hydrolyze the structural $\beta$-1,3-glucan present in some fungal cell wall. Three cDNA clones corresponding to different $\beta$-1,3-glucanase genes from grapevine have been characterized previously (Jacobs et al. 1999). The rtq-PCR analysis (Fig. 2B) revealed that, in lami- narin-treated grapevine cells, GLU1 transcripts accumulated from $15 \mathrm{~h}$ of treatment with a 150 -fold increase within $25 \mathrm{~h}$.

Inhibitors of serine proteases (PIN) have emerged as a class of antifungal PR-6 proteins which have potent activity against plant and animal pathogens (Van Loon and Van Strien 1999).
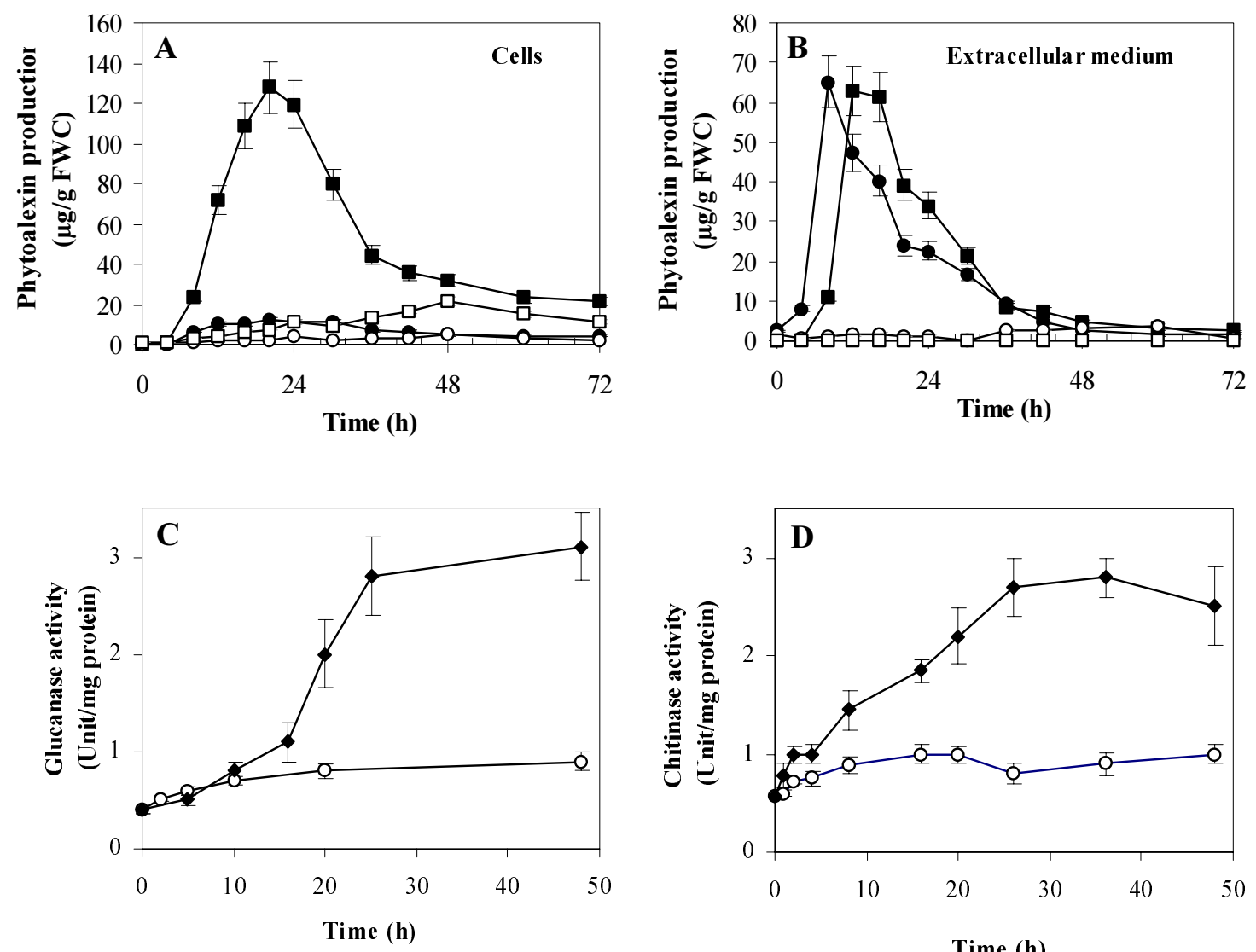

Time (h)

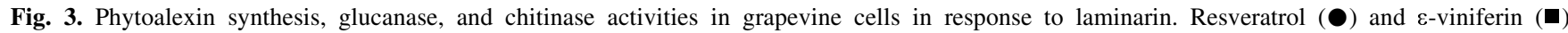
production measured in $\mathbf{A}$, the cellular fraction or $\mathbf{B}$, the extracellular medium of cell suspensions treated with laminarin at $1 \mathrm{~g} /$ liter or in control cell suspensions (resveratrol, $\bigcirc$ and $\varepsilon$-viniferin, $\square$ ). $\mathbf{C}$, Glucanase and $\mathbf{D}$, chitinase activities in cell extracts from cell suspensions treated with laminarin at 1 $\mathrm{g} /$ liter $(\bullet)$ or in untreated cells $(\bigcirc)$. Values represent the mean \pm SD of duplicate assays of one representative experiment out of three.
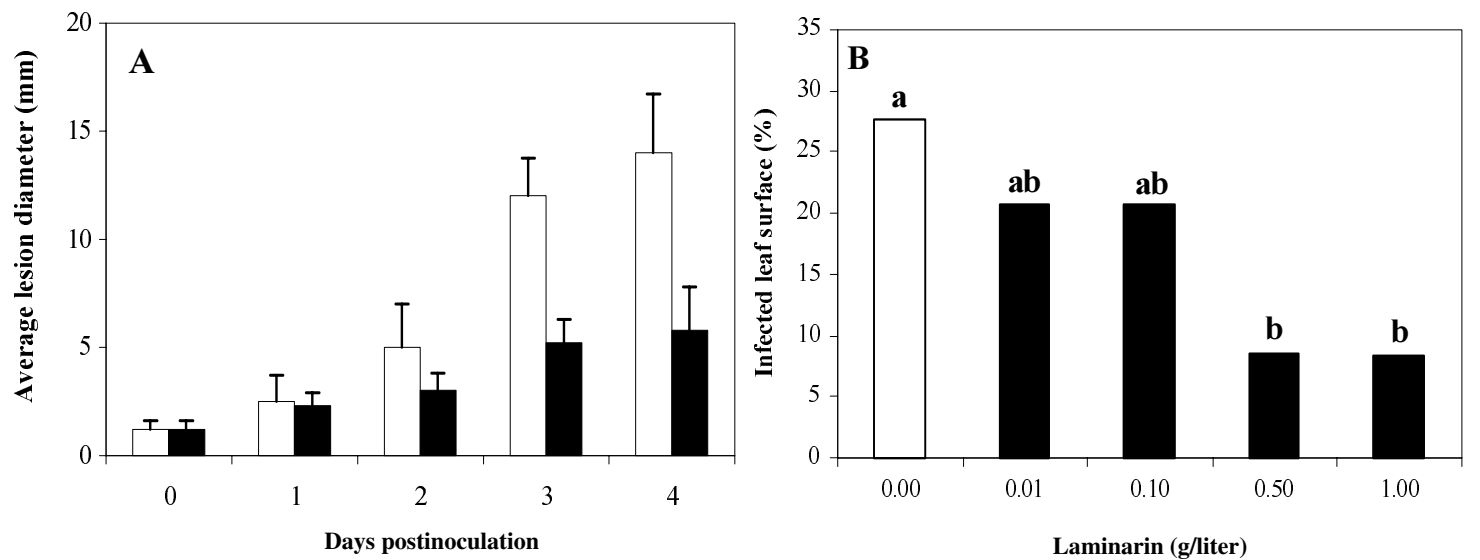

Fig. 4. Laminarin-induced protection of grapevine leaves against Botrytis cinerea and Plasmopara viticola. A, Effect of laminarin on the protection of grapevine leaves against the fungus $B$. cinerea. Detached leaves were incubated for $24 \mathrm{~h}$ on aqueous solutions containing laminarin at $1 \mathrm{~g} /$ liter before inoculation with a conidial suspension $\left(5 \times 10^{5}\right.$ conidia/ml $)$ of $B$. cinerea (40 leaves per condition). Disease assessment was determined measuring the average diameter of lesions formed during 4 days post inoculation. Data represent the average diameter \pm SD of lesions spreading on 40 elicited leaves (black bars) compared with untreated ones (open bars). Results are from one representative experiments out of four. Asterisk indicates that values are significantly different $(P<0.05)$ according to $c$ test. B, Development of downy mildew $(P$. viticola $)$ on grapevine plants treated with laminarin. Plants were sprayed with increasing concentrations of laminarin and inoculated 10 days later by spraying a sporangial suspension $\left(2 \times 10^{4} \mathrm{sporangia} / \mathrm{ml}\right)$. Disease assessment was done 8 days post inoculation and expressed as percent infected leaf surface. Fourteen plants were used per treatment. Results with different letters are significantly different at 5\% using Duncan's multiple range test. The experiment was repeated twice with similar results. 
The rtq-PCR analysis revealed that the PIN gene was up-regulated in grapevine cells after $5 \mathrm{~h}$ of laminarin treatment (Fig. 2B), reaching approximately 600-fold within 20 to $25 \mathrm{~h}$ of elicitation.

An increase of the expression of these genes also was monitored in detached grapevine leaves treated with laminarin at 1 g/liter. Accumulation of mRNA corresponding to CHIT1b, CHIT4c, GLU1, and PIN reached a 110-, 525-, 125-, and 410fold higher level, respectively, than in control detached leaves after $24 \mathrm{~h}$ of treatment (Fig. 2C).

\section{Laminarin did not induce either HSR gene expression or cell death.}

A cDNA showing significant homology with the tobacco HSR 203 cDNA has been isolated by differential display reverse transcriptase PCR from grapevine leaves infected with B. cinerea (Bézier et al. 2002b). In tobacco, HSR203 mRNA accumulation occurs during the HR and is considered to be a marker of cell death (Pontier et al. 1998). Antisense expression of HSR203 in tobacco triggered an accelerated cell death, suggesting that its product counteracts the cell death process (Tronchet et al. 2001). Elsewhere, HSR203 is not expressed in response to various biotic stresses or elicitors which did not induce HR (Brederode et al. 1991; Godiard et al. 1991; Pontier et al. 1998). rtq-PCR results indicated that this grapevine $H S R$ homologue was not up-regulated by laminarin (data not shown). Furthermore, grapevine cell viability, quantified by neutral red as a vital dye (Naton et al. 1996), was not significantly altered in the presence of laminarin even at a high concentration. The cells remained 95 to $97 \%$ viable after a 24-h treatment with laminarin at $1 \mathrm{~g} / \mathrm{liter}$ (data not shown). These results clearly indicate that laminarin did not induce any HR in grapevine cells. When applied on whole plants, laminarin at $1 \mathrm{~g} /$ liter did not induce cell death (data not shown).

\section{Laminarin induces phytoalexin production and increases chitinase and $\beta-1,3$-glucanase activities.}

Resveratrol and its dimer, $\varepsilon$-viniferin, are the major phytoalexins produced by grape (Vitis spp.) in response to microbial attacks and UV (Adrian et al. 1997; Coutos-Thévenot et al. 2001; Langcake and Pryce 1977a and b; Pryce and Langcake 1977). Large amounts of both phytoalexins were produced by grapevine cells in response to laminarin (Fig. 3A and B). Most of the resveratrol accumulated in the extracellular medium, where it peaked $8 \mathrm{~h}$ after treatment ( $65 \mu \mathrm{g} / \mathrm{g}$ FWC). $\varepsilon$-viniferin was present predominantly inside the cells, where it peaked $(130 \mu \mathrm{g} / \mathrm{g}$ FWC $)$ after $20 \mathrm{~h}$, though a significant amount of $\varepsilon$ viniferin $(62 \mu \mathrm{g} / \mathrm{g}$ FWC) was detected after $12 \mathrm{~h}$ in the extracellular medium. Subsequently, both compounds progressively disappeared from both the cells and the extracellular medium (Fig. 3A and B). The amounts of phytoalexins were very low in control cells and the corresponding extracellular medium (2 $\mu \mathrm{g} / \mathrm{g}$ FWC).

To determine if the accumulation of transcripts corresponding to chitinase and $\beta$-1,3-glucanase genes correlates with an increase of chitinase and $\beta$-1,3-glucanase activities, respectively, crude enzyme extracts were prepared from laminarintreated as well as control grapevine cells. Results showed an increase in both intracellular chitinase and $\beta$-1,3-glucanase activities after 4 and $10 \mathrm{~h}$, respectively, of laminarin treatment (Fig. 3C and D). Both activities peaked after $25 \mathrm{~h}$ of treatment and remained high throughout the experimental period. In control cells, both activities were very low. In detached grapevine leaves treated for $24 \mathrm{~h}$ with laminarin at $1 \mathrm{~g} /$ liter, chitinase activity increased from $0.23 \pm 0.1$ (control) to $2.17 \pm 0.5 \mathrm{Unit} / \mathrm{g}$ of FW leaves (treated).

\section{Laminarin-induced protection}

of grapevine against $B$. cinerea and $P$. viticola.

Leaves detached from in vitro cultivated grapevine plantlets were preincubated on different concentrations of laminarin for $24 \mathrm{~h}$, then inoculated with a $B$. cinerea conidial suspension of 5 $\times 10^{5}$ conidia $/ \mathrm{ml}$. Under these conditions, the average diameter of lesions measured 4 days post inoculation was reduced by approximately $55 \%$ in the leaves treated with laminarin at 1 g/liter (Fig 4A). With laminarin at 0.5 and $0.2 \mathrm{~g} / \mathrm{liter}$, this reduction reached 40 and $15 \%$, respectively (data not shown).

In a second series of assays, laminarin-triggered protection against $P$. viticola was measured using whole plants ( $V$. vinifera cv. Gamay) sprayed on both leaf surfaces with different concentrations of laminarin. A first series of assays indicated that laminarin-induced protection was evident after 8 days of treatment. Thus, whole plants were used instead of detached leaves and plants were inoculated 10 days after laminarin application by spraying a sporangial suspension $\left(2 \times 10^{4}\right.$ sporangia/ml $)$ on the lower face of leaves. Disease intensity was estimated 8 days post inoculation by measuring the leaf area covered by the oomycete and counting the sporangia. Our data (Fig. 4B) indicate that laminarin at 0.5 to $1 \mathrm{~g} /$ liter reduced the percentage of $P$. viticola-infected leaf surfaces from $28 \%$ in the control to $7 \%$ in the laminarin-sprayed plants, corresponding to a $75 \%$ reduction in infection.

\section{DISCUSSION}

\section{Laminarin triggers a typical}

elicitor signal transduction network in grapevine cells.

When supplied to grapevine cell suspensions, laminarin triggers a series of events, within minutes of treatment, typical of those described for other, well-known elicitors (Fig. 1). In grapevine cells, laminarin (as well as oligogalacturonides; data not shown) induces a rapid calcium influx, similar to that obtained in tobacco cells, which has been reported to trigger a biphasic and transient free-calcium elevation in the cytosol (Lecourieux et al. 2002). Calcium influx and increase in free cytosolic calcium concentration have been reported to occur in response to various abiotic and biotic stimuli, particularly to elicitors (Blume et al. 2000; Knight et al. 1991; Lecourieux et al. 2002; Mithöfer et al. 1999; Tavernier et al. 1995). In common with other elicitors, laminarin induces the alkalinization of the extracellular medium of grapevine cells (Boller 1995). As reported with laminarin-treated tobacco cells (Klarzynski et al. 2000), this alkalinization is transient, which suggests the activation of plasma membrane (PM) $\mathrm{H}^{+}$-ATPases in a second step, to restore the $\mathrm{pH}$ gradient between the apoplast and the cytosol. Laminarin also triggers, within moments of treatment, a transient production of $\mathrm{H}_{2} \mathrm{O}_{2}$. AOS can have antimicrobial effects (Baker and Orlandi 1995) and are assumed to be involved in lipid peroxidation (Rustérucci et al. 1996), oxidative cross linking of cell wall proteins (Bradley et al. 1992; Brisson et al. 1994), phytoalexin production (Jabs et al. 1997), and defense gene expression related to HR and SAR (Alvarez et al. 1998; Chen et al. 1993; Costet et al. 2002; Levine et al. 1994). Nevertheless, the role of AOS, as a signal, is not restricted to plant-pathogen interactions, and their putative roles in SAR and in HR-like cell death has been the subject of debate, with the species and the level of AOS determining for the type of response (Delledone et al. 2001; Rustérucci et al. 1996; Van Breusegem et al. 2001). In plants, many MAPK modules participate in the transduction of various biotic or abiotic stimuli (Asai et al. 2002; Hirt 1997; Lee et al. 1998). In tobacco, salicylic acid-induced protein kinase (SIPK) and wound-induced protein kinase (WIPK) are two MAPKs activated in response to various elicitors, including cryptogein and oligogalacturonides 
(Lebrun-Garcia et al. 1998; Zhang et al. 1998). In grapevine cells, laminarin triggers a fast and transient phosphorylationdependent activation of two MAPKs with relative molecular masses of 49 and $45 \mathrm{kDa}$, respectively, suggesting a conserved phosphorylation cascade in this species.

\section{Laminarin induces defense gene expression, accumulation} of phytoalexins, chitinase, and $\beta-1,3$-glucanase activities.

In elicitor- or pathogen-treated plants, important changes in the plant transcriptome pattern have been reported (Baldwin et al. 1999; Dangl and Jones 2001; Maleck et al. 2000; Schenk et al. 2000). rtq-PCR has been used to analyze the expression of 11 defense-related genes in grapevine cell suspensions and leaves treated with laminarin (Fig. 2). In cells, 10 of these genes were up-regulated in response to the algal $\beta$-1,3-glucan, whereas HSR, which is considered to be an HR-like marker gene of cell death in tobacco (Pontier et al. 1998), was not induced. This observation is consistent with our results, indicating that laminarin did not induce any cell death. Elsewhere, some of these genes were activated rapidly after laminarin treatment (LOX, GST, PAL, STS1, CHIT4c, and CHIT1b), whereas others were up-regulated later (CHIT3, PIN, GLU1, and PGIP). A 9-LOX could be essential for the resistance to fungal infection, as it was demonstrated in tobacco using an antisense strategy (Rancé et al. 1998). The gene expression of GST, an enzyme which takes part in the detoxification of elicitor-generated oxidants, has been reported in response to the oxidative burst (Levine et al. 1994; Mauch and Düdler 1993; Vanacker et al. 2000). The induction of PAL and STS1 genes is consistent with the production of resveratrol and $\varepsilon$-viniferin, two phytoalexins involved in the protection against pathogens (Coutos-Thevenot et al. 2001; Hain et al. 1993; Stark-Lorenzen et al. 1997). PGIPs are considered to favor plant defenses by preventing plant cell wall degradation and modulating some fungal polygalacturonase activities (De Lorenzo and Ferrari 2002), thus releasing elicitor-active long-chained oligogalacturonides.

Laminarin-treated cells also exhibit an induction of genes encoding different families of $P R$ proteins with antimicrobial properties (Fritig et al. 1998; Van Loon and Van Strien 1999). The expression of the three chitinase genes occurred rapidly after laminarin treatment. Moreover, the CHIT4c transcripts were very abundant, whereas $C H I T 3$ amounts were low and $C H I T 1 b$ quantities were intermediate. The analysis of the expression of some of these genes in grapevine leaves treated with laminarin confirmed the transcript accumulation monitored in cells, and particularly CHIT4c (Fig. 2C). In the same manner, Derckel and associates (1998) showed that the class IV chitinase, $\mathrm{CHV}$, is the most abundant chitinase produced in response to fungal challenge in ripening grape berries. $C H I T 1 b$ and $C H I T 3$ were activated in grapevine treated with a yeast elicitor or salicylic acid.

As expected, laminarin also triggers a large production of both phytoalexins, resveratrol and $\varepsilon$-viniferin. Interestingly, resveratrol was detected mainly in the extracellular medium, whereas its dimer, $\varepsilon$-viniferin, was much more abundant in cell extracts (Fig. 3A and B). In cells, both phytoalexins are not sequestered in vacuoles (E. Martinoïa, personal communication) and the presence of large amounts of $\varepsilon$-viniferin suggests a rapid dimerization of resveratrol. The presence of both compounds in the extracellular medium could result from the transport or diffusion of these compounds or their conjugates through the PM to the apoplast, where, as previously reported, they exert their antibiotic activities (Coutos-Thevenot et al. 2001). Alternatively, extracellular $\varepsilon$-viniferin could result from an oxidative coupling of resveratrol triggered by a cell-wall-localized peroxidase (Calderon et al. 1992, 1994; Langcake and
Pryce 1977c). Comparisons of kinetics of accumulation of both compounds in cells and extracellular medium support this process, though further experiments are required to verify this assumption.

The activities of both chitinase and glucanase increased in laminarin-treated cells of grapevine (Fig. 3C and D), correlating to the accumulation of the corresponding transcripts (Fig. 2B). In grapevine leaves treated for $24 \mathrm{~h}$ with laminarin at 1 $\mathrm{g} /$ liter, chitinase activity was 10 -fold higher than in the control. This result is in agreement with the induction of chitinase genes in laminarin-treated leaves (Fig. 2C).

Both enzyme activities should participate in the plant defense by hydrolyzing fungal cell wall components as previously reported (Van Loon and Van Strien 1999). They also should amplify the plant defense by releasing $\beta-1,3$ glucans and chitin fragments from the pathogen cell walls, both oligosaccharides being well known elicitors (Côté et al. 1998). Thus, laminarin triggers a variety of defense responses in grapevine (our results) and in tobacco (Klarzynski et al. 2000).

\section{Defense responses induced by laminarin lead}

\section{to grapevine protection against $B$. cinerea and $P$. viticola.}

When applied on detached grapevine leaves or on intact plantlets, laminarin 0.5 to $1 \mathrm{~g} /$ liter reduced the development of $B$. cinerea and $P$. viticola by approximately 50 and $75 \%$, respectively (Fig. 4). Further protection is conceivable by improving the penetration of the elicitor and by better characterizing the optimum time for defense activation. These assays are in progress. Laminarin also confers protection of tobacco to the soft rot disease agent, Erwinia carotovora (Klarzynski et al. 2000), indicating that this compound could be effective across a large spectrum of plant species and against different pathogens, although laminarin probably will not be efficient against all of them. Taken together, these data show that the activation of plant defenses using elicitors is probably a valuable alternative strategy to restrict the pathogen spread.

\section{MATERIALS AND METHODS}

\section{Biological materials.}

Grapevine ( $V$. vinifera cv. Gamay) cell suspensions were cultivated in Nitsch-Nitsch medium (Nitsch and Nitsch 1969) without added hormone on a rotary shaker $\left(150 \mathrm{rpm}, 25^{\circ} \mathrm{C}\right)$ under continuous light $\left(2,000 \mathrm{ergs} / \mathrm{cm}^{2}\right)$. Cells were subcultured every 7 days to be maintained in exponential phase and 1-day-prior assays. Vitro-plantlets of grapevine ( $V$. vinifera cv. Chardonnay 75) were grown in the Murashige and Skoog (1962) medium at $26^{\circ} \mathrm{C}$ with a photoperiod of $14 \mathrm{~h}$ of light. Grapevine plants ( $V$. vinifera $\mathrm{cv}$. Gamay) were obtained from cuttings cultivated in a growth chamber at $25^{\circ} \mathrm{C}$ with a day length of $18 \mathrm{~h}$.

B. cinerea (Botryotinia fuckeliana p. f.) strain 630 (kind gift of Y. Brygoo, INRA, Versailles, France) was grown on potato dextrose in $250-\mathrm{ml}$ flasks at $22^{\circ} \mathrm{C}$.

A $P$. viticola isolate collected in Burgundy in 2001 was maintained on potted grapevine plants and subcultured every week.

\section{Preparation of laminarin.}

Laminarin was extracted and purified from the marine brown algae $L$. digitata by the firm Goëmar as described by Klarzynski and associates (2000). Thus, the same laminarin preparation was tested for elicitor activity on both tobacco (Klarzynski et al. 2000) and grapevine (this work) cells and plants. The average degree of polymerization (DP) of laminarin was estimated by molecular size chromatography coupled with a refractometric detector. Purity, size, and structure were analyzed further by 
natural abundance ${ }^{13} \mathrm{C}$ nuclear magnetic resonance spectroscopy and high performance anion exchange chromatography and pulsed amperometric detection (Lépagnol-Descamps et al. 1998), confirming that laminarin is an essentially linear $\beta-1,3-$ glucan of a mean DP of 33 .

\section{Treatments.}

Cells were collected during the exponential growth phase and washed by filtration in a suspension buffer containing 175 $\mathrm{mM}$ mannitol, $0.5 \mathrm{mM} \mathrm{K}_{2} \mathrm{SO}_{4}, 0.5 \mathrm{mM} \mathrm{CaCl}_{2}$, and $2 \mathrm{mM}$ MES (morpholineethanesulfonic acid) adjusted to $\mathrm{pH}$ 5.4. Cells were resuspended at $0.1 \mathrm{~g} \mathrm{FW} / \mathrm{ml}$ with suspension buffer and equilibrated for $2 \mathrm{~h}$ on a rotary shaker $\left(150 \mathrm{rpm}, 24^{\circ} \mathrm{C}\right)$. Grapevine cells then were used for measurements of calcium influx, $\mathrm{H}_{2} \mathrm{O}_{2}$ production, extracellular $\mathrm{pH}$, protein kinase activation, and cell death after treatment with laminarin. Control cells were incubated under the same conditions without elicitor.

For gene expression, chitinase activity, and resveratrol production, cells were collected during the exponential growth phase and resuspended at $0.1 \mathrm{~g} \mathrm{FW} / \mathrm{ml}$ in a freshly prepared cell culture medium and equilibrated for $2 \mathrm{~h}$ on a rotary shaker $\left(130 \mathrm{rpm}, 24^{\circ} \mathrm{C}\right)$ before the addition of elicitor.

\section{Measurement of medium alkalinization.}

Grapevine cells in suspension buffer ( $\mathrm{pH} 5.4)$ were equilibrated for $1 \mathrm{~h}$ with continuous stirring until a steady $\mathrm{pH}$ value was reached. The change in medium $\mathrm{pH}$ was monitored with a glass combination electrode for $70 \mathrm{~min}$ after laminarin supply.

\section{$\mathrm{H}_{2} \mathrm{O}_{2}$ production measurement.}

$\mathrm{H}_{2} \mathrm{O}_{2}$ production was determined using chemiluminescence of luminol as described previously (Poinssot et al. 2003). Chemiluminescence, measured within a 10 -s period with a luminometer, (Lumat LB 9507, Berthold) was integrated and expressed in nanomole of $\mathrm{H}_{2} \mathrm{O}_{2}$ per gram of FWC using a standard calibration curve obtained by $\mathrm{H}_{2} \mathrm{O}_{2}$ addition in grapevine cell suspension aliquots.

\section{$\mathrm{Ca}^{2+}$ influx measurement.}

Five minutes before treatments, cells in the suspension buffer (pH 5.4) were incubated with ${ }^{45} \mathrm{Ca}^{2+}\left(0.033 \mathrm{MBq} \mathrm{g}{ }^{-1}\right.$ FWC; Amersham Pharmacia Biotech). After different periods of treatment, triplicate $1.5-\mathrm{ml}$ aliquots were filtered under vacuum on glass microfiber (GF/A) filters and washed three times with a total volume of $25 \mathrm{ml}$ of buffer (175 mM mannitol, 0.5 $\mathrm{mM} \mathrm{K} \mathrm{SO}_{4}, 5 \mathrm{mM} \mathrm{LaCl}$, and $2 \mathrm{mM} \mathrm{MES,} \mathrm{pH} \mathrm{5.4)} \mathrm{before}$ transferring the cells to scintillation vials. After a $12-\mathrm{h}$ period at $65^{\circ} \mathrm{C}$, dry weight was determined and $10 \mathrm{ml}$ of Ready Safe cocktail (Beckman) were added to the vials before counting in a scintillation counter (TRI-CARB 2100 TR, Packard).

\section{MAP kinase activation monitored}

by Western blotting assays.

Detection of nonactivated or activated MAPKs was performed as described elsewhere (Poinssot et al. 2003).

\section{Phytoalexin quantification.}

At different times after treatment, aliquots $(2 \mathrm{ml})$ of cells in the culture medium were collected and filtered on GF/A glass fiber filters. Filtrates were directly analyzed, whereas stilbenes from the cell fraction were extracted in $2 \mathrm{ml}$ of methanol overnight at $4^{\circ} \mathrm{C}$. Each sample $(40 \mu \mathrm{l})$ was loaded onto a Lichrocart C-18 inverse phase column (250 by $4 \mathrm{~mm}, 5 \mu \mathrm{m}$; Merck) equilibrated with a 90/10 ( $\mathrm{vol} / \mathrm{vol}) \mathrm{H}_{2} \mathrm{O} /$ acetonitrile mobile phase. Phytoalexins were eluted with a linear gradient from 10 to $85 \%$ acetonitrile at a flow rate of $1 \mathrm{ml} \mathrm{min}^{-1}$. Quantification of trans-resveratrol and $\varepsilon$-viniferin was performed with stan- dard calibration curves using peak areas of different amounts of pure molecules fluorometrically detected $(\lambda \mathrm{ex}=330 \mathrm{~nm}$, $\lambda \mathrm{em}=374 \mathrm{~nm}$ ), as previously described (Jeandet et al. 1997).

\section{Northern blot analysis and rtq-PCR.}

Aliquots of grapevine cell suspensions $(2 \mathrm{ml})$ in the culture medium were filtered and subsequently frozen in liquid $\mathrm{N}_{2}$. Total RNA isolation was obtained by adding $1 \mathrm{ml}$ of trizol (Gibco-BRL) following the manufacturer's procedure.

For Northern blot analysis, $10 \mu \mathrm{g}$ of total RNA were separated on a $1.2 \%$ agarose gel containing $1.1 \%$ formaldehyde, then transferred to a Hybond $\mathrm{N}^{+}$membrane (Amersham Pharmacia Biotech) and crosslinked by UV. The blot was hybridized at $65^{\circ} \mathrm{C}$ with cDNA probes labeled with $50 \mu \mathrm{Ci}\left[\alpha-{ }^{32} \mathrm{P}\right]-$ dCTP using the Ready-To-Go labeling kit (Amersham Pharmacia Biotech). Blots were exposed for $24 \mathrm{~h}$ in a phosphorimager screen or to X-Omat AR film (Kodak).

For rtq-PCR, total RNA were incubated with 15 units of RNase-free DNase I (Promega Corp.) for $30 \mathrm{~min}$ at $37^{\circ} \mathrm{C}$ and stopped with a phenol:chloroform:isoamylic alcohol mixture (25:24:1, vol/vol/vol). DNase-treated RNA ( $2 \mu \mathrm{g})$ was reverse transcribed with $5 \mu \mathrm{M}$ of oligo(dT) following the manufacturer's instructions (Life Technologies/Gibco-BRL). The transcript levels were determined by rtq-PCR using the GeneAmp 5700 Sequence Detector (Applied Biosystems) using the SYBR Green Master Mix PCR kit as recommended by the manufacturer (Applied Biosystems). PCR reactions were carried out in triplicates in 96 -well plates $(25 \mu \mathrm{l}$ per well) in a reaction buffer containing $1 \times$ SYBR Green I mix (including Taq polymerase, dNTPs, SYBR Green dye), $300 \mathrm{nM}$ forward and reverse primers, and a 1:250 dilution of reverse-transcribed RNA. After denaturation at $95^{\circ} \mathrm{C}$ for $10 \mathrm{~min}$, amplification occurred in a two-step procedure: $15 \mathrm{~s}$ of denaturation at $95^{\circ} \mathrm{C}$ and $1 \mathrm{~min}$ of annealing and extension at $60^{\circ} \mathrm{C}$, with a total of 40 cycles. Identical thermal cycling conditions were used for all targets. The gene-specific primers are indicated in Table 1. The absence of primer-dimer formation, which could interfere with specific amplification, was checked in controls lacking templates. Transcript level was calculated using the standard curve method (User Bulletin \#2; ABI PRISM 7700 Sequence Detection System, Applied Biosystems). Standard curves were generated by performing rtq-PCR on serial dilutions of specific purified DNA. This latter consisted of a PCR product prepared by "classical" PCR from plasmid harboring the target gene as template. The copy number $(\mathrm{CN})$ for these PCR products used as standards was calculated from their concentration measured by absorbance at $260 \mathrm{~nm}$. Standard curves were constructed by plotting the threshold cycle (Ct values, PCR cycle at which the reporter fluorescence of SYBR Green above the baseline signal can be detected) versus the logarithm of the $\mathrm{CN}$ of specific purified PCR products. The absolute $\mathrm{CN}$ for each sample was calculated from standard curves using their $\mathrm{Ct}$ value and normalized against grapevine actin gene as internal control (Bézier et al. 2002a) and nontreated cells as reference sample. Subsequently, for each gene, the reference sample was referred as the $1 \times$ expression level and results were expressed as the fold increase of mRNA level over the reference sample.

\section{Chitinase and glucanase activity assays.}

Chitinase activity was measured according to the procedure described by Wirth and Wolf (1992) using carboxymethyl/chitin/Remazol/brilliant violet $5 \mathrm{R}$ as a substrate. For $\beta$ 1,3-glucanase assays, proteins from the crude extract $(0.5 \mathrm{ml})$ were precipitated with $80 \%$ ammonium sulfate and redissolved in $0.5 \mathrm{ml}$ of $50 \mathrm{mM}$ sodium acetate buffer, $\mathrm{pH}$ 5.0. $\beta-1,3-\mathrm{Glu}-$ canase activity was assayed according to Derckel and associates (1998) using laminarin (Flucka) as a substrate. 


\section{Cell death determination.}

The vital dye neutral red was used to test for cell death. Accumulation of the dye within the vacuole was observed by light microscopy. Cells not stained by neutral red were considered dead (Naton et al. 1996). A neutral red aqueous stock solution of $1 \mathrm{mg} \mathrm{ml}^{-1}$ was diluted for staining to a final concentration of $0.01 \%$ (wt/vol) in suspension buffer, $\mathrm{pH} \mathrm{7.5}$. Aliquots of $1 \mathrm{ml}$ of cell suspension were examined in triplicates for each laminarin concentration.

\section{Protection assays.}

For B. cinerea infections, conidia were collected with $10 \mathrm{ml}$ of sterile water on a 10-day-old potato dextrose liquid culture, filtered to remove mycelia and counted. For each treatment, 40 leaves were excised from 10-week-old grapevine vitro-plantlets and pre-incubated on a standard buffer ( $2 \mathrm{mM}$ MES, 0.5 $\mathrm{mM} \mathrm{CaCl} 2,0.5 \mathrm{mM} \mathrm{K}_{2} \mathrm{SO}_{4}, \mathrm{pH}$ 5.9) containing various concentrations of laminarin $(0.01,0.1,0.2,0.5$, and $1.0 \mathrm{~g} / \mathrm{liter})$. After $24 \mathrm{~h}$, the leaves were wrapped in wet absorbing paper and placed on plastic petri dishes. One needle-prick wound was applied to each leaf, and the fresh wounds were covered with $5-\mu l$ drops of a suspension of $5 \times 10^{5}$ conidia/ml. Quantification of disease development in grapevine leaves after inoculation with $B$. cinerea was measured as average diameter of lesions formed during infection.

For Plasmopara viticola infections, plants carrying 12 to 15 expanded leaves were first sprayed on both leaf surfaces with solutions of laminarin at various concentrations $(0.01,0.1,0 ., 5$ and $1.0 \mathrm{~g} /$ liter). Héliosol (Samabiol), a tensio-active additive, was added at $0.1 \%(\mathrm{vol} / \mathrm{vol})$ in all sprayed solutions, including water control. Fourteen plants were used per treatment. Treated plants were kept in a growth chamber $\left(25^{\circ} \mathrm{C}, 18 \mathrm{~h}\right.$ of daylight, 60 to $70 \%$ relative humidity $[\mathrm{RH}]$ ) for 10 days, then inoculated by spraying a sporangial suspension of $2 \times 10^{4}$ sporangia $/ \mathrm{ml}$ onto the lower face of leaves. Inoculated plants were transferred to a dew chamber $\left(100 \% \mathrm{RH}, 20^{\circ} \mathrm{C}\right.$, darkness) for one night and then in a growth chamber $\left(23^{\circ} \mathrm{C}, 18\right.$-h photoperiod, 60 to $70 \% \mathrm{RH}$ ) for 8 days. Sporulation was induced afterward by placing plants in the dew chamber as described above. Disease intensity was estimated 8 days post inoculation by measuring the leaf area covered with mycelia and counting the sporangia. In the latter method, leaves were washed with $50 \%$ ethanol and sporangia were counted with a hematocytometer. Both methods gave similar results.

Statistical analysis was performed by analysis of variance and Duncan's multiple range test.

\section{ACKNOWLEDGMENTS}

This work was supported by the Bureau Interprofessionnel des Vins de Bourgogne and the Regional Councils of Burgundy and Champagne. We thank F. Baillieul for providing the sequences of primers used for real time quantitative PCR and helpful discussions, K. Gould for reviewing the English manuscript, and A. Klinguer for excellent technical assistance.

\section{LITERATURE CITED}

Adrian, M., Jeandet, P., Veneau, J., Weston, L. A., and Bessis, R. 1997. Biological activity of resveratrol, a stilbenic compound from grapevines, against Botrytis cinerea, the causal agent for gray mold. J. Chem. Ecol. 23:1689-1702.

Alvarez, M. E., Pennell, R. I., Meijer, P. J., Ishikawa, A., Dixon, R. A., and Lamb, C. 1998. Reactive oxygen intermediates mediate a systemic signal network in the establishment of plant immunity. Cell 92:773784.

Asai, T., Tena, G., Plotnikova, J., Willmann, M. R., Chiu, W. L., GomezGomez, L., Boller, T., Ausubel, F. M., and Sheen, J. 2002. MAP kinase signalling cascade in Arabidopsis innate immunity. Nature 415:977-983.
Bais, A. J., Murphy, P. J., and Dry, I. B. 2000. The molecular regulation of stilbene phytoalexin biosynthesis in Vitis vinifera during grape berry development. Aust. J. Plant Physiol. 27:425-433.

Baker, C. J., and Orlandi, E. W. 1995. Active oxygen in plant pathogenesis. Annu. Rev. Phytopathol. 33:299-321.

Baldwin, D., Crane, V., and Rice, D. 1999. A comparison of gel-based, nylon filter and microarray techniques to detect differential RNA expression in plants. Curr. Opin. Plant Biol. 2:96-103.

Bézier, A., Lambert, B., and Baillieul, F. 2002a. Study of defense-related gene expression in grapevine leaves infected with Botrytis cinerea. Eur. J. Plant Pathol. 108:111-120.

Bézier, A., Lambert, B., and Baillieul, F. 2002b. Cloning of a grapevine Botrytis-responsive gene that has homology to the tobacco hypersensitivity-related hsr203J. J. Exp. Bot. 53:2279-2280.

Blume, B., Nürnberger, T., Nass, N., and Scheel, D. 2000. Receptor-mediated increase in cytoplasmic free calcium required for activation of pathogen defense in parsley. Plant Cell 12:1425-1440.

Boller, T. 1995. Chemoperception of microbial signals in plant cells. Annu. Rev. Plant Physiol. Plant Mol. Biol. 46:489-214.

Bouarab, K., Potin, P., Correa, J., and Kloareg, B. 1999. Sulfated oligosaccharides mediate the interaction between a marine red alga and its green algal pathogenic endophyte. Plant Cell 11:1635-1650

Bradley, D. J., Kjellbom, P., and Lamb, C. J. 1992. Elicitor- and woundinduced oxidative cross-linking of a proline-rich plant cell wall protein: a novel, rapid defense response. Cell 70:21-30.

Brady, K. P., Darvill, A. G., and Albersheim, P. 1993. Activation of a tobacco glycine-rich protein gene by a fungal glucan preparation. Plant J. 4:517-524.

Brederode, F. T., Linthorst, H. J., and Bol, J. F. 1991. Differential induction of acquired resistance and PR gene expression in tobacco by virus infection, ethephon treatment, UV light and wounding. Plant Mol. Biol. 17:1117-1125.

Brisson, L. F., Tenhaken, R., Lamb, C. 1994. Function of oxidative crosslinking of cell wall structural proteins in plant disease resistance. Plant Cell 6:1703-1712.

Busam, G., Kassemeyer, H. H., and Matern, U. 1997. Differential expression of chitinases in Vitis vinifera L. responding to systemic acquired resistance activators or fungal challenge. Plant Physiol. 115:10291038 .

Calderon, A., Zapata, J. M., and Barcelo, A. R. 1994. Peroxidase-mediated formation of resveratrol oxidation products during the hypersensitive-like reaction of grapevine cells to an elicitor from Trichoderma viride. Physiol. Mol. Plant Pathol. 44:289-299.

Calderon, A., Zapata, J. M., Pedreno, M., Munoz, R., and Barcelo, A. R. 1992. Levels of 4-hydroxystilbene-oxidizing isoperoxidases related to constitutive disease resistance in in vitro-cultured grapevine. Plant Cell Tissue Organ Cult. 29:63-70.

Caprari, C., Mattei, B., Basile, M. L., Salvi, G., Crescenzi, V., De Lorenzo, G., and Cervone, F. 1996. Mutagenesis of endopolygalacturonase from Fusarium monoliforme: histidine residue 234 is critical for enzymatic and macerating activities and not for binding to polygalacturonase-inhibiting protein (PGIP). Mol. Plant-Microbe Interact. 9:617-624.

Cardinale, F., Jonak, C., Ligterink, W., Niehaus, K., Boller, T., and Hirt, H. 2000. Differential activation of four specific MAPK pathways by distinct elicitors. J. Biol. Chem. 275:36734-36740.

Chen, Z., Silva, H., and Klessig, D. F. 1993. Active oxygen species in the induction of plant systemic acquired resistance by salicylic acid. Science 262:1883-1886.

Cheong, J. J., and Hahn, M. G. 1991. A specific, high-affinity binding site for the hepta- $\beta$-glucoside elicitor exists in soybean membranes. Plant Cell. 3:137-147.

Costet, L., Dorey, S., Fritig, B., and Kauffman, S. 2002. A pharmacological approach to test the diffusible signal activity of reactice oxygen intermediates in elicitor-treated tobacco leaves. Plant Cell Physiol. 43:91-98.

Côté, F., and Hahn, M. G. 1994. Oligosaccharins: structures and signal transduction. Plant Mol. Biol. 26:1379-1411.

Côté, F., Laflamme, L., Payet, M. D., and Gallot-Payet, N. 1998. Oligosaccharide elicitors in host-pathogen interactions. Generation, perception, and signal transduction. Subcell. Biochem. 29:385-432.

Coutos-Thévenot, P., Poinssot, B., Bonomelli, A., Yean, H., Breda, C., Buffard, D., Esnault, R., Hain, R., and Boulay, M. 2001. In vitro tolerance to Botrytis cinerea of grapevine 41B rootstock in transgenic plants expressing the stilbene synthase Vst1 gene under the control of a pathogen-inducible PR10 promoter. J. Exp. Bot. 358:901-910.

Dangl, J. L., and Jones, J. D. G. 2001. Plant pathogens and integrated defense responses to infection. Nature 411:826-833.

Darvill, A., Augur, C., Bergmann, C., Carlson, R. W., Cheong, J. J., Eberhard, S., Hahn, M. G., Lo, V. M., Marfa, V., Meyer, B., Mohnen 
D., O’Neill, M. A., Spiro, M. D., van Halbeck, H., York, W. S., and Albersheim, P. 1992. Oligosaccharins-oligosaccharides that regulates growth, development and defense responses in plants. Glycobiology 2:181-198.

Davies, C., and Robinson, S. P. 2000. Differential screening indicates a dramatic change in mRNA profiles during grape berry ripening. Cloning and characterization of cDNAs encoding putative cell wall and stress response proteins. Plant Physiol. 122:803-812.

Delledone, M., Zeier, J., Marocco, A., and Lamb, C. 2001. Signal interactions between nitric oxide and reactive oxygen intermediates in the plant hypersensitive response. Proc. Natl. Acad. Sci. U.S.A. 98:1345413459.

De Lorenzo, G., and Ferrari, S. 2002. Polygalacturonase-inhibiting proteins in defense against phytopathogenic fungi. Curr. Opin. Plant Biol. 5:295-299.

Derckel, J. P., Audran, J. C., Haye, B., Lambert, B., and Legendre, L. 1998. Characterization, induction by wounding and salicylic acid, and activity against Botrytis cinerea of chitinases and B-1,3-glucanases of ripening grape berries. Physiol. Plant. 104:56-64.

Derckel, J. P., Legendre, L., Audran, J. C., Haye, B., and Lambert, B. 1996. Chitinase of the grapevine (Vitis vinifera L.): five isoforms induced in leaves by salicylic acid are constitutively expressed in others tissues. Plant Sci. 119:31-37.

Ebel, J., and Cosio, E. G. 1994. Elicitors of plant defense responses. Int. Rev. Cytol. 148:1-36.

Felix, G., Baureithel, K., and Boller, T. 1998. Desensitization of the perception system for chitin fragments in tomato cells. Plant Physiol. 117:643-650.

Felix, G., Regenass, M., and Boller, T. 1993. Specific perception of subnanomolar concentrations of chitin fragments by tomato cells: induction of extracellular alkalinization, changes in protein phosphorylation, and establishment of refractory state. Plant J. 4:307-316.

Fritig, B., Heitz, T., and Legrand, M. 1998. Antimicrobial proteins in induced plant defense. Curr. Opin. Immunol. 10:16-22.

Godiard, L., Froissard, D., Fournier, J., Axelos, M., and Marco, Y. 1991 Differential regulation in tobacco cell suspensions of genes involved in plant-bacteria interactions by pathogen-related signals. Plant Mol. Biol. 17:409-413.

Gomez-Gomez, L., and Boller, T. 2002. Flagellin perception : a paradigm for innate immunity. Trends Plant Sci. 7:251-256.

Hain, R., Reif, H., Krause, E., Langebartels, R., Kindl, H., Vornam, B., Wiese, W., Schmelzer, E., Schreier, P. H., Stocker, R. H., and Stenzel, K. 1993. Disease resistance results from foreign phytoalexin expression in a novel plant. Nature 361:153-156.

Hammerschmidt, R. 1999. Phytoalexins: what have we learned after 60 years? Annu. Rev. Phytopathol. 37:285-306.

Hirt, H. 1997. Multiple roles of MAP kinases in plant signal transduction. Trends Plant Sci. 2:11-15.

Inui, H., Yamaguchi, Y., and Hirano, S. 1997. Elicitor actions of N-acetylchitooligosaccharides and laminarioligosaccharides for chitinase and L-phenylalanine ammonia-lyase induction in rice suspension culture. Biosci. Biotechnol. Biochem. 61:975-978.

Jabs, T., Tschope, M., Colling, C., Hahlbrock, K., and Scheel, D. 1997. Elicitor-stimulated ion fluxes and $\mathrm{O}_{2}^{-}$from the oxidative burst are essential components in triggering defense gene activation and phytoalexin synthesis in parsley. Proc. Natl. Acad. Sci. U.S.A. 94:48004805 .

Jacobs, A. K., Dry, I. B., and Robinson, S. P. 1999. Induction of different pathogenesis-related cDNAs in grapevine infected with powdery mildew and treated with ethephon. Plant Pathol. 48:325-336.

Jeandet, P., Bessis, R., and Gautheron, B. 1991. The production of resveratrol (3,5,4'-trihydrostilbene) by grape berries in different developmental stages. Am. J. Enol. Vitic. 42:41-46.

Jeandet, P., Breuil, A. C., Adrian, M., Weston, L. A., Debord, S., Meunier, P., Maume, G., and Bessis, R. 1997. HPLC analysis of grapevine phytoalexins coupling photodiode array detection and fluorimetry. Anal. Chem. 69:5172-5177.

John, M., Schmidt, J., Walden, R., Czaja, I., Dulz, M., Schell, J., and Rohrig, H. 1997. Lipo-chitooligosaccharide-induced tobacco cells release a peptide as mediator of the glycolipid signal. Proc. Natl. Acad. Sci. U.S.A. 94:10178-10182.

Klarzynski, O., Plesse, B., Joubert, J. M., Yvin, J. C., Kopp, M., Kloareg, B., and Fritig, B. 2000. Linear $\beta$-1,3-glucans are elicitors of defense responses in tobacco. Plant Physiol. 124:1027-1037.

Knight, M. R., Campbell, A. K., Smith, S. M., and Trewavas, A. J. 1991. Transgenic plant aequorin reports the effects of touch and cold-shock and elicitors on cytoplasmic calcium. Nature 352:524-526.

Küpper, F. C., Kloareg, B., Guern, J., and Potin, P. 2001. Oligoguluronates elicit an oxidative burst in the brown algal kelp Laminaria digitata. Plant Physiol. 125:278-291.
Langcake, P., and Pryce, R. J. 1977a. A new class of phytoalexins from grapevines. Experientia 33:151-152.

Langcake, P., and Pryce, R. J. 1977b. The production of resveratrol and the viniferins by grapevines in response to ultraviolet irradiation. Phytochemistry 16:1193-1196.

Langcake, P., and Pryce, R. J. 1977c. Oxidative dimerisation of 4 hydroxystilbenes in vitro: production of a grapevine phytoalexin mimic. J. C. S. Chem. Comm. 7:208-210.

Lebrun-Garcia, A., Ouaked, F., Chiltz, A., and Pugin, A. 1998. Activation of MAPK homologues by elicitors in tobacco cells. Plant J. 15:773781.

Lecourieux, D., Mazars, C., Pauly, N., Ranjeva, R., and Pugin, A. 2002. Analysis and effects of cytosolic free calcium increases in response to elicitors in Nicotiana plumbaginifolia cells. Plant Cell 14:2627-2641.

Lee, J. Y., Yoo, B. C., and Harmon, A. C. 1998. Kinetic and calciumbinding properties of three calcium-dependent protein kinase isoenzymes from soybean. Biochemistry 37:6801-6809.

Lépagnol-Descamps, V., Richard, C., Lahaye, M., Potin, P., Yvin, J. C., and Kloareg, B. 1998. Purification and determination of the action of Haliotis tuberculata laminarinase. Carbohydr. Res. 310:283-289.

Leroux, P., Chapeland, F., Desbrosses, D., and Gredt, M. 1999. Patterns of cross-resistance to fungicides in Botryotinia fuckeliana (Botrytis cinerea) isolates from French vineyards. Crop Prot. 18:687-697

Levine, A., Tenhaken, R., Dixon, R., and Lamb, C. 1994. $\mathrm{H}_{2} \mathrm{O}_{2}$ from the oxydatif burst orchestrates the plant hypersensitive disease resistance response. Cell 79:583-593.

Maleck, K., Levine, A., Eulgem, T., Morgan, A., Schmid, J., Lawton, K. A., Dangl, J. L., and Dietrich, R. A. 2000. The transcriptome of Arabidopsis thaliana during systemic acquired resistance. Nat. Genet. 26:403-410.

Mathieu, Y., Sanchez, F. J., Droillard, M. J., Lapous, D., Lauriere, C., and Guern, J. 1996. Involvement of protein phosphorylation in the early steps of transduction of the oligogalacturonide signal in tobacco cells. Plant Physiol. Biochem. 34:399-408.

Mauch, F., and Dudler, R. 1993. Differential induction of distinct glutathione-S-transferases of wheat by xenobiotics and by pathogen attack. Plant Physiol. 102:1193-1201.

Melchior, F., and Kindl, H. 1990. Grapevine stilbene synthase cDNA only slightly differing from chalcone synthase cDNA is expressed in Escherichia coli into a catalytically active enzyme. FEBS (Fed. Eur. Biochem. Soc.) Lett. 268:17-20.

Melchior, F., and Kindl, H. 1991. Coordinate- and elicitor- dependent expression of stilbene synthase and phenylalanine ammonia-lyase genes in Vitis cv. Optima. Arch. Biochem. Biophys. 288:552-557.

Mithöfer, A., Ebel, J., Bhagwat, A. A., Boller, T., and Neuhaus, G. 1999. Transgenic aequorin monitors cytosolic calcium transients in soybean cells challenged with $\beta$-glucan or chitin elicitors. Planta 207:566-574.

Murashige, T., and Skoog, A. 1962. A revised medium for rapid growth and bioassays with tobacco tissue cultures. Physiol. Plant. 15:473-497.

Naton, B., Hahlbrock, K., and Schmelzer, E. 1996. Correlation of rapid cell death with metabolic changes in fungus-infected, cultured parsley cells. Plant Physiol. 112:433-434.

Nitsch, J. P., and Nitsch, C. 1969. Haploid plants from pollen grains. Science 169:85.

Poinssot, B., Vandelle, E., Bentéjac, M., Adrian, M., Levis, C., Brygoo, Y., Garin, J., Sicilia, F., Coutos-Thévenot, P., and Pugin, A. 2003. The endopolygalacturonase 1 from Botrytis cinerea activates grapevine defence reactions unrelated to its enzymatic activity. Mol. Plant-Microbe Interact. 16:553-564

Pontier, D., Tronchet, M., Rogowsky, P., Lam, E., and Roby, D. 1998. Activation of $h s r 203$, a plant gene expressed during incompatible plantpathogen interactions, is correlated with programmed cell death. Mol Plant-Microbe Interact. 11:544-554.

Potin, P., Bouarab, K., Kupper, F., and Kloareg, B. 1999. Oligosaccharide recognition signals and defence reactions in marine plant-microbe interactions. Curr. Opin. Microbiol. 2:276-283.

Pryce, R. J., and Langcake, P. 1977. alpha-viniferin: an antifungal resveratrol trimer from grapevines. Phytochemistry 16:1452-1454.

Rancé, I., Fournier, J., and Esquerré-Tugaye, M. T. 1998. The incompatible interaction between Phytophthora parasitica var. nicotianae race 0 and tobacco is suppressed in transgenic plants expressing antisense lipoxygenase sequences. Proc. Natl. Acad. Sci. U.S.A. 95:6554-6559

Robert, N., Ferran, J., Breda, C., Coutos-Thévenot, P., Boulay, M. Buffard, D., and Esnault, R. 2001. Molecular characterization of the incompatible interaction of Vitis vinifera leaves with Pseudomonas syringae pv. pisi : expression of genes coding for stilbene synthase and class 10 PR protein. Eur. J. Plant Pathol. 107:249-261.

Robert, N., Roche, K., Lebeau, Y., Breda, C., Boulay, M., Esnault, R. and Buffard, D. 2002. Expression of grapevine chitinase genes in ber- 
ries and leaves infected by fungal or bacterial pathogens. Plant Sci. 162:389-400

Robinson, S. P., Jacobs, A. K., and Dry, I. B. 1997. A class IV chitinase is highly expressed in grape berries during ripening. Plant Physiol. 114:771-778.

Romeis, T., Piedras, P., Zhang, S., Klessig, D. F., Hirt, H., and Jones, J. D. G. 1999. Rapid Avr9- and Cf-9-dependent activation of MAP kinases in tobacco cell cultures and leaves: Convergence of resistance gene, elicitor, wound, and salicylate responses. Plant Cell 11:273-287.

Rouhier, P., Kopp, M., Begot, V., Bruneteau, M., and Fritig, B. 1995. Structural features of fungal beta-D-glucans for the efficient inhibition of the initiation of virus infection on Nicotiana tabacum. Phytochemistry 39:57-62.

Rustérucci, C., Stallaert, V., Milat, M. L., Pugin, A., Ricci, P., and Blein, J. P. 1996. Relationship between active oxygen species, lipid peroxidation, necrosis, and phytoalexin production induced by elicitins in Nicotiana. Plant Physiol. 111:885-891.

Salzman, R. A., Tikhonova, I., Bordelon, B. P., Hasegawa, P. M., and Bressan R. A. 1998. Coordinate accumulation of antifungal proteins and hexoses constitutes a developmentally controlled defense response during fruit ripening in grape. Plant Physiol. 117:465-472.

Schenk, P. M., Kazan, K., Wilson, I., Anderson, J. P., Richmond, T., Somerville, S. C., and Manners, J. M. 2000. Coordinated plant defense responses in Arabidopsis revealed by microarray analysis. Proc. Natl. Acad. Sci. U.S.A. 97:11655-11660.

Sharp, J. K., Valent, B., and Albersheim, P. 1984. Purification and partial characterisation of a $\beta$-glucan fragment that elicits phytoalexin accumulation in soybean. J. Biol. Chem. 259:11312-11320.

Somssich, I. E., and Hahlbrock, K. 1998. Pathogen defense in plants-a paradigm of biological complexity. Trends Plant Sci. 3:86-90.

Sparvoli, F., Martin, C., Scienza, A., Gavazzi, G., and Tonelli, C. 1994. Cloning and molecular analysis of structural genes involved in flavonoid ans stilbene biosynthesis in grape (Vitis vinifera L.). Plant Mol. Biol. 24:743-755
Stark-Lorenzen, P., Nelke, B., Hänssler, G., Mühlbach, H. P., and Thomzik, J. E. 1997. Transfer of a grapevine stilbene synthase gene to rice (Oriza sativa L). Plant Cell Rep. 16:668-673.

Tavernier, E., Wendehenne, D., Blein, J. P., and Pugin, A. 1995. Involvement of free calcium in action of cryptogein, a proteinaceous elicitor of hypersensitive reaction in tobacco cells. Plant Physiol. 109:10251031 .

Tronchet, M., Ranty, B., Marco, Y., and Roby, D. 2001. HSR203 antisense suppression in tobacco accelerates development of hypersensitive cell death. Plant J. 27:115-127.

Vanacker, H., Carver, T. L. W., and Foyer, C. H. 2000. Early $\mathrm{H}_{2} \mathrm{O}_{2}$ accumulation in mesophyll cells leads to induction of glutathione during the hyper-sensitive response in the barley-powdery mildew interaction. Plant Physiol. 123:1289-1300.

Van Breusegem, F., Vranova, E., Dat, J. F., and Inzé, D. 2001. The role of active oxygen species in plant signal transduction. Plant Sci. 161:405411.

Van Loon, L. C., and Van Strien, E. A. 1999. The families of pathogenesis-related proteins, their activities, and comparative analysis of PR-1 type proteins. Physiol. Mol. Plant Pathol. 55:85-97.

Wiese, W., Vornam, B., Krause, E., and Kindl, H. 1994. Structural organization and differential expression of three stilbene synthase genes located on a $13 \mathrm{~Kb}$ grapevine cDNA fragment. Plant Mol. Biol. 26:667677.

Wirth, S. J., and Wolf, G. A. 1992. Microplate colorimetric assay for endo-acting cellulase, xylanase, chitinase, $\beta$-1,3-glucanase and amylase extracted from forest soil horizons. Soil Biol. Biochem. 24:511519.

Yang, K. Y., Shah, J., and Klessig, D. F. 1997. Signal perception and transduction in plant defense responses. Genes Dev. 11:1621-1639.

Zhang, S., Du, H., and Klessig, D. F. 1998. Activation of the tobacco SIP kinase by both a cell wall-derived carbohydrate elicitor and purified proteinaceous elicitins from Phytophthora spp. Plant Cell $10: 435-449$ 